\title{
A new chemically defined medium for the growth and sporulation of Bacillus cereus strains in anaerobiosis
}

\author{
Amina Aicha Abbas, Stella Planchon ${ }^{1}$, Michel Jobin, Philippe Schmitt* \\ INRA, UMR408 Sécurité et Qualité des Produits d'Origine Végétale, "F-84000 Avignon, France \\ Université d'Avignon et des Pays de Vaucluse, UMR408 Sécurité et Qualité des Produits d'Origine Végétale, France
}

\begin{abstract}
A B S T R A C T
A new chemically defined liquid medium, MODS, was developed for the aerobic growth and anaerobic growth and sporulation of Bacillus cereus strains. The comparison of sporulation capacity of 18 strains of $B$. cereus has shown effective growth and spore production in anaerobiosis..
\end{abstract}

Keywords:

B. cereus

Anaerobiosis

Sporulation

MODS medium

Chemically defined sporulation medium

\section{Introduction}

Bacillus cereus is a pathogenic bacterium producing toxins responsible for emetic and diarrheal syndromes (Carlin et al., 2000; Ceuppens et al., 2013; Ehling-Schulz et al., 2004). Soil is considered as the natural habitat of this bacterium. Consequently, vegetables, milk and rice are frequently contaminated with $B$. cereus. This facultative anaerobic, Gram-positive bacterium forms spores under environmental stress such as nutrient deprivation (Moir et al., 2002; Setlow et al., 2003; Setlow and Johnson, 2007).

Spores are a differentiated cell type consisting of metabolically dormant cells, able to resist chemical and physical stresses such as air-drying, high temperature, high pressure, UV light and acidity (Clavel et al., 2004; Nguyen Thi Minh et al., 2011; Setlow, 2006; Tam et al., 2006). This resistance is due to the presence of several specific layers and the high dehydration level of the spore core (de Vries et al., 2005).

Sporulation media commonly used in laboratories are complex, with common features such as a high level of nutrients with a combination of peptones, yeast extract, casamino acids and minerals such as iron, magnesium, calcium, copper, manganese and zinc, presence or absence

\footnotetext{
* Corresponding author at: INRA, UMR408, Site Agroparc, 84914 Avignon Cedex 9 , France. Tel.: +3343272 2545 .

E-mail address: philippe.schmitt@univ-avignon.fr (P. Schmitt).

1 Present address: CTCPA - UMT Qualiveg. Site Agroparc, 449 avenue Clément-Ader, ZA de l'Aéroport - BP21203, 84911 Avignon Cedex 9.
}

of agar, and an optimal pH value close to 7.0 (Meyer and Tholozan, 1999; Ting and Fung, 1972). Among these media, CCY (Casein-Casein-Yeast), FNA (Fortified Nutrient Agar) and $2 \times$ SG (double-strength Schaeffer sporulation medium) are routinely used to study the sporulation of Bacillus strains (Fernandez et al., 1999; Stewart et al., 1981). In these media, spore-forming bacteria grow until depletion of the medium, and then sporulate spontaneously. Growth and sporulation are closely linked. These media thus lead to heterogeneous and poorly reproducible production of spores (de Vries et al., 2004).

Currently, chemically defined synthetic media for growth and sporulation are frequently used (de Vries et al., 2004; de Vries et al., 2005; Donnellan et al., 1964; Ellar and Lundgren, 1966; Glatz and Koepfert, 1976; Hageman et al., 1984; Ramaley and Burden, 1970; Ting and Fung, 1972; Rosenfeld et al., 2005). In most of these studies, sporulation was performed in aerobiosis. However, B. cereus is able to develop in a broad range of oxygen-depleted environments (intestine, soil or on a food processing line). B. cereus vegetative cells can sporulate in such anaerobic environments and cause serious problem of food safety. However, Bacillus sporulation in anaerobiosis had not been specifically studied.

The aim of this work was to develop a new chemically defined liquid medium for growth and sporulation of $B$. cereus in both aerobiosis and anaerobiosis. The medium consisted of a modification of the basal medium MOD (Rosenfeld et al., 2005). First, we compared aerobic and anaerobic growth and sporulation parameters between the MOD medium, MOD modified medium (MODS) and the CCY sporulation medium, which is frequently used for Bacillus sporulation (Stewart et al., 1981). 
Version définitive du manuscrit publiée dans / Final version of the manuscript published in :

Journal of Microbiological Methods (2014), Vol. 105, p. 54-58, DOI: 10.1016/j.mimet.2014.07.006

Journal homepage: http://www.elsevier.com/locate/jmicmeth

\section{Materials and methods}

\subsection{Micro-organisms, growth and sporulation media}

Eighteen B. cereus strains were used in this study (Table 1). These strains belonged to phylogenetic groups II, III, IV, V, VI and VII as defined by Guinebretière et al. (2008). In order to study the capacity of sporulation, three media were used in this work: the sporulation medium CCY (Stewart et al., 1981), the chemically defined MOD medium (Rosenfeld et al., 2005) and the new chemically defined medium named MODS. For the latter, the basal medium MOD was firstly quarter-diluted, and then supplemented with $10 \mathrm{mM}$ glucose and minerals including $\mathrm{MgCl}_{2}(0.5 \mathrm{mM}) ; \mathrm{MnCl}_{2}(0.01 \mathrm{mM}) ; \mathrm{ZnCl}_{2}(0.05 \mathrm{mM})$; and $\mathrm{CaCl}_{2}$ $(0.2 \mathrm{mM})$. Finally, the $\mathrm{pH}$ of MODS was adjusted to 7.2 with $\mathrm{KOH}$. The composition of each medium is given in Table 2 .

\subsection{Culture conditions and spore production}

Growth was performed in uncontrolled batch cultures in the different media. For growth and sporulation in MOD and MODS media, overnight cultures of the $B$. cereus strains were grown with stirring $(200 \mathrm{rpm})$ in MOD supplemented with $30 \mathrm{mM}$ glucose. For growth and sporulation in CCY medium, an overnight culture in LB (Luria-Bertani) broth was performed. Incubation was performed at $30^{\circ} \mathrm{C}$ for strains belonging to phylogenetic groups II, V and VI, and $37{ }^{\circ} \mathrm{C}$ for strains belonging to phylogenetic groups III, IV and VII. After $18 \mathrm{~h}$ incubation, cultures were centrifuged at $7000 \times g$ for 5 min at room temperature, and cells were suspended in CCY, MOD or MODS media. For experiments in anaerobiosis, the cultures were performed in Hungate tubes filled with $12 \mathrm{ml}$ of medium and equipped with caps and rubber septa. To eliminate all traces of oxygen, a flow of $\mathrm{N}_{2}$ was sent through a Hungate column and sparged into the medium. The aerobic cultures were performed in $500 \mathrm{ml}$ conical flasks containing $100 \mathrm{ml}$ of medium. All the cultures were performed in triplicate.

\subsection{Measure of growth and sporulation}

Growth was followed using a spectrophotometer (Helios Epsilon; Thermo Scientific, Rockford, IL). To prevent oxygen entering uncontrolled anaerobiosis cultures, tubes were not opened to measure $A_{600}$ values. Consequently, the growth was followed without the dilution of cultures for which the optical density was outside the linearity curve from the spectrophotometer. Nevertheless, dilutions have been performed at the end of growth: the samples showing an $A_{600}$ greater than 0.3 were
Table 2

Composition of the different media used: MOD, MODS and CCY.

\begin{tabular}{|c|c|c|c|}
\hline & \multirow[b]{2}{*}{ MOD } & \multicolumn{2}{|c|}{ Concentration $\left(\mathrm{g} \mathrm{l}^{-1}\right)$} \\
\hline & & MODS & CCY \\
\hline Total amino acids & 10.41 & 2.61 & 2.4 (including casamino acid $\left(1 \mathrm{gl}^{-1}\right)$ \\
\hline L-Arginine & 0.46 & 0.12 & 0 \\
\hline L-Aspartic acid & 0.91 & 0.23 & 0 \\
\hline L-Cysteine & 0.04 & 0.01 & 0 \\
\hline L-Glutamic acid & 2 & 0.50 & 0 \\
\hline Glycine & 0.39 & 0.10 & 0 \\
\hline L-Histidine & 0.36 & 0.09 & 0 \\
\hline L-Isoleucine & 0.7 & 0.18 & 0 \\
\hline L-Leucine & 1.37 & 0.34 & 0 \\
\hline L-Lysine & 1.18 & 0.30 & 0 \\
\hline L-Methionine & 0.4 & 0.10 & 0 \\
\hline L-Phenylalanine & 0.28 & 0.07 & 0 \\
\hline L-Serine & 0.66 & 0.17 & 0 \\
\hline L-Threonine & 0.71 & 0.18 & 0 \\
\hline L-Tyrosine & 0.042 & 0.01 & 0 \\
\hline L-Valine & 0.91 & 0.23 & 0 \\
\hline L-Glutamine & 0 & 0 & 0 \\
\hline Glycerol & 0 & 0 & 0.6 \\
\hline Pastone & 0 & 0 & 1 \\
\hline Yeast extract & 0 & 0 & 0.4 \\
\hline $\mathrm{K}_{2} \mathrm{HPO}_{4}, 3 \mathrm{H}_{2} \mathrm{O}$ & 1 & 0.25 & 5.93 \\
\hline $\mathrm{KH}_{2} \mathrm{PO}_{4}$ & 0 & 0 & 1.768 \\
\hline$\left(\mathrm{NH}_{4}\right)_{2} \mathrm{SO}_{4}$ & 6 & 1.50 & 0 \\
\hline $\mathrm{MgSO}_{4}, 7 \mathrm{H}_{2} \mathrm{O}$ & 0.04 & 0.01 & 0 \\
\hline $\mathrm{MgCl}_{2}, 6 \mathrm{H}_{2} \mathrm{O}$ & 0 & 0.1 & 0.1 \\
\hline $\mathrm{MnCl}_{2}, 4 \mathrm{H}_{2} \mathrm{O}$ & 0 & 0.002 & 0.002 \\
\hline $\mathrm{CaCl}_{2}, 6 \mathrm{H}_{2} \mathrm{O}$ & 0 & 0.043 & 0.043 \\
\hline $\mathrm{ZnCl}_{2}$ & 0 & 0.007 & 0.007 \\
\hline $\mathrm{FeCl}_{3}, 6 \mathrm{H}_{2} \mathrm{O}$ & 0 & 0.013 & 0.013 \\
\hline Glucose & 5.4 & 1.8 & 0 \\
\hline $\mathrm{pH}$ & 7.2 & 7.2 & 7 \\
\hline
\end{tabular}

diluted with sterile medium before measurement to maintain linearity of absorbance and cell mass.

To follow the growth and sporulation of the 18 strains, the concentration of vegetative cells and spores was determined by plating cells on the appropriate growth media and after heating at $70{ }^{\circ} \mathrm{C}$ for 10 min to kill any vegetative cells. The serial decimal dilutions of cultures were made in $0.1 \mathrm{M}$ phosphate buffer, $\mathrm{pH}$ 7.0. An aliquot of $100 \mu \mathrm{l}$ of each dilution was plated on LB-agar medium and incubated at $30{ }^{\circ} \mathrm{C}$ for $24 \mathrm{~h}$. Cell and spore concentrations were expressed in colony-forming units per $\mathrm{ml}\left(\mathrm{CFU} \mathrm{ml}{ }^{-1}\right)$.

Table 1

Characteristics of the strains used in this study.

\begin{tabular}{|c|c|c|c|}
\hline B. cereus strain designation & Origin & Temperature growth limits $\left({ }^{\circ} \mathrm{C}\right)$ & Phylogenic group ${ }^{a}$ \\
\hline NVH 0861-00 & Diarrheal outbreak & $7-40$ & II \\
\hline Bc 05-F1 & Soil & & II \\
\hline INRA 15 & Food & & II \\
\hline F4810/72 & Emetic outbreak & $15-45$ & III \\
\hline DSMZ 4222 & Clinical infection & & III \\
\hline $\mathrm{F} 4433 / 73$ & Diarrheal outbreak & & III \\
\hline $\mathrm{F} 4430 / 73$ & Diarrheal outbreak & $10-40 / 45$ & IV \\
\hline ATCC14579 & Type strain B. cereus & & IV \\
\hline NVH1230 & / & & IV \\
\hline F2769/77 & Diarrheal outbreak & $10-40$ & V \\
\hline NVH 141/1-01 & Diarrheal outbreak & & $\mathrm{V}$ \\
\hline UHDAM TSP9 & Environment & & V \\
\hline INRA KBAB4 & Environment & $5 / 7-37$ & VI \\
\hline SDA NFFE 664 & Environment & & VI \\
\hline WSBC 10204 T & Type strain $B$. weihens & & VI \\
\hline NVH883/00 & Diarrheal outbreak & $20-50$ & VII \\
\hline AFSSA 08CEB44bac & Diarrheal outbreak & & VII \\
\hline NVH 391-98 & Diarrheal outbreak & & VII \\
\hline
\end{tabular}

\footnotetext{
a The phylogenetic groups as defined by Guinebretière et al. (2008).
} 


\section{Version définitive du manuscrit publiée dans / Final version of the manuscript published in : \\ Journal of Microbiological Methods (2014), Vol. 105, p. 54-58, DOI: 10.1016/ị.mimet.2014.07.006 \\ Journal homepage: http://www.elsevier.com/locate/jmicmeth}

Spore production was monitored using a phase contrast microscope (Olympus BX 50 instrument, Rungis, France). When free phase-bright spores $(>90 \%)$ were obtained, harvesting and purification of spores were performed at $4{ }^{\circ} \mathrm{C}$ to prevent germination. The culture was first centrifuged at $8500 \mathrm{~g}$ for $15 \mathrm{~min}$, and then washed with cold distilled water and centrifuged with decreasing rotor speeds $(8500 \times \mathrm{g}, 6500 \times \mathrm{g}$ and $5500 \times \mathrm{g}$ ) for $15 \mathrm{~min}$. The pellet obtained from each centrifugation was suspended in cold distilled water. After harvesting, the spores were pasteurized at $70{ }^{\circ} \mathrm{C}$ for $10 \mathrm{~min}$ to eliminate any vegetative cells, and cooled in an ice bath. Spore suspensions were stored at $4{ }^{\circ} \mathrm{C}$ until use.

\section{Results}

\subsection{Growth kinetics in MOD, MODS and CCY media}

The growth of 18 strains from the B. cereus group was carried out in an uncontrolled batch culture in the MOD, MODS and CCY media at pH 7.2 in aerobiosis and anaerobiosis (Table 3). Incubation was performed at $30{ }^{\circ} \mathrm{C}$ for strains belonging to phylogenetic groups II, $\mathrm{V}$ and $\mathrm{VI}$ or $37^{\circ} \mathrm{C}$ for strains belonging to phylogenetic groups III, IV and VII. Growth kinetics was studied by monitoring optical density at $600 \mathrm{~nm}$.

In anaerobiosis, maximal OD in the stationary phase was lower than that in aerobiosis. In aerobiosis, maximal density was closely similar for the strains belonging to phylogenic groups II, III, IV, V and VI, and ranged from $2.06 \pm 0.11$ to $4 \pm 0.21$ (spores $\mathrm{ml}^{-1}$ ) in MOD medium, from $1.43 \pm 0.10$ to $3.59 \pm 0.04$ (spores $\mathrm{ml}^{-1}$ ) in MODS medium and from $1.45 \pm 0.26$ to $3.58 \pm 0.42$ (spores $\mathrm{ml}^{-1}$ ) in CCY medium. In anaerobiosis, the average final density in MODS was lower than that in MOD. It ranged from $0.19 \pm 0.04$ to $0.81 \pm 0.01$ (spores $\mathrm{ml}^{-1}$ ) and from $0.43 \pm 0.03$ to $1.24 \pm 0.09$ (spores $\mathrm{ml}^{-1}$ ) in MODS and MOD media, respectively. No growth was observed in the CCY medium in anaerobiosis. In addition, strains of group VII did not grow in the tested media, in aerobiosis or anaerobiosis, except for the 08CEB44 strain, which grew in CCY medium in aerobiosis.

\subsection{Ability of B. cereus sporulation in MOD, MODS and CCY media}

Eighteen strains belonging to the different phylogenetic groups of B. cereus (II, III, IV, V, VI and VII) were selected to study their ability to sporulate in the MODS medium in aerobiosis or anaerobiosis (Table 4). Capacity to sporulate was compared with MOD and CCY media. Spores were counted after heating the cell suspension to evaluate ability to sporulate.

In aerobiosis, no significant difference in the capacity to sporulate of the strains belonging to phylogenic groups II, III, IV, V and VI was observed between the MODS and CCY media. In both media, all the strains sporulated with an average of $8 \times 10^{8}$ spores $\mathrm{ml}^{-1}$ and $2.61 \times 10^{8}$ spores $\mathrm{ml}^{-1}$, respectively. No sporulation was obtained in the MOD medium for any strain as confirmed by microscopic observations. As no growth was observed in anaerobiosis in the CCY medium, no spores were produced in these conditions.

In anaerobic conditions, the maximum spore production in the MODS medium was lower (average of $5 \times 10^{4}$ spores $\mathrm{ml}^{-1}$ ) than that in the aerobic conditions. The highest number of spores produced was obtained for the strain AH $187\left(6.75 \times 10^{5}\right.$ spores $\left.\mathrm{ml}^{-1}\right)$ and the lowest for the $\mathrm{F} 4430 / 73$ strain $\left(2.73 \times 10^{1}\right.$ spores $\left.\mathrm{ml}^{-1}\right)$. In addition, as no growth was observed in either aerobiosis or anaerobiosis for strains belonging to phylogenic group VII in the tested media, no spores were produced, except for the 08CEB44 strain, which produced spores in CCY medium only in aerobiosis.

\section{Discussion}

B. cereus is a foodborne pathogen able to produce spores (Ceuppens et al., 2013). Little information was available on B. cereus sporulation in the absence of oxygen because most studies on sporulation had been performed in aerobic conditions (Planchon et al., 2011; Nguyen Thi Minh et al., 2011). However, B. cereus is a facultative anaerobic bacterium, able to grow in a broad variety of environments where oxygen level may range widely. In anaerobic conditions such as intestine, soil and food processing lines, $B$. cereus vegetative cells can sporulate, and the spores have different properties from those of spores produced in aerobiosis.

In order to determine whether B. cereus sporulation is possible in anaerobiosis, we optimized an existing medium, MOD, to allow effective growth and sporulation in the absence and presence of oxygen. The MOD medium is a chemically defined medium, frequently used to study the effect of nutrients and/or physicochemical factors on growth parameters, growth adaptation (Senouci-Rezkallah et al., 2011, Thomassin et al., 2006), substrate metabolism or toxin production in B. cereus species (Duport et al., 2004, Ouhib et al., 2006, Ouhib et al.,

Table 3

Growth of $B$. cereus strains in MOD, CCY and MODS media in aerobiosis and anaerobiosis.

\begin{tabular}{|c|c|c|c|c|c|c|c|}
\hline \multirow[b]{3}{*}{ Strains } & \multirow{2}{*}{\multicolumn{3}{|c|}{ MOD }} & \multirow{2}{*}{$\frac{\text { Growth }^{\mathrm{a}}}{\mathrm{CCY}}$} & \multirow[t]{2}{*}{$\left(A_{600}\right)$} & \multirow{2}{*}{\multicolumn{2}{|c|}{ MODS }} \\
\hline & & & & & & & \\
\hline & Phylogenetic groups & Aerobiosis & Anaerobiosis & Aerobiosis & Anaerobiosis & Aerobiosis & Anaerobiosis \\
\hline D15 & & $3.24 \pm 0.58$ & $0.85 \pm 0.12$ & $3.58 \pm 0.42$ & $N G^{b}$ & $2.71 \pm 0.25$ & $0.56 \pm 0.20$ \\
\hline KBAA5 & II & $3.18 \pm 0.18$ & $0.61 \pm 0.18$ & $2.75 \pm 0.19$ & NG & $2.24 \pm 0.28$ & $0.44 \pm 0.04$ \\
\hline INRA 15 & & $2.81 \pm 0.23$ & $0.77 \pm 0.12$ & $2.97 \pm 0.20$ & & $2.05 \pm 0.11$ & $0.44 \pm 0.08$ \\
\hline AH187 & & $3.31 \pm 0.11$ & $0.43 \pm 0.03$ & $2.04 \pm 0.05$ & NG & $2.93 \pm 0.04$ & $0.19 \pm 0.04$ \\
\hline F837/76 & III & $3.61 \pm 0.22$ & $0.66 \pm 0.07$ & $3.01 \pm 0.16$ & NG & $3.00 \pm 0.13$ & $0.63 \pm 0.02$ \\
\hline F4433/73 & & $3.57 \pm 0.28$ & $0.93 \pm 0.11$ & $3.27 \pm 0.17$ & & $2.56 \pm 0.28$ & $0.73 \pm 0.03$ \\
\hline $\mathrm{F} 4430 / 73$ & & $3.88 \pm 0.2$ & $1.24 \pm 0.09$ & $2.67 \pm 0.03$ & NG & $2.68 \pm 0.18$ & $0.64 \pm 0.01$ \\
\hline ATCC14579 & IV & $3.53 \pm 0.03$ & $0.78 \pm 0.02$ & $2.05 \pm 0.07$ & NG & $2.38 \pm 0.05$ & $0.80 \pm 0.02$ \\
\hline NVH1230 & & $3.18 \pm 0.19$ & $0.80 \pm 0.07$ & $2.37 \pm 0.22$ & & $2.80 \pm 0.30$ & $0.69 \pm 0.03$ \\
\hline F2769/77 & & $3.61 \pm 0.07$ & $0.64 \pm 0.13$ & $2.65 \pm 0.12$ & NG & $2.38 \pm 0.24$ & $0.55 \pm 0.02$ \\
\hline NVH 141/1-01 & V & $2.06 \pm 0.11$ & $0.66 \pm 0.10$ & $3.03 \pm 0.17$ & NG & $2.69 \pm 0.12$ & $0.47 \pm 0.05$ \\
\hline UHDAM TSP9 & & $3.70 \pm 0.02$ & $0.55 \pm 0.06$ & $1.71 \pm 0.21$ & & $1.43 \pm 0.10$ & $0.40 \pm 0.04$ \\
\hline КВАВ4 & & $3.70 \pm 0.02$ & $1.18 \pm 0.07$ & $2.11 \pm 0.02$ & NG & $2.80 \pm 0.09$ & $0.81 \pm 0.01$ \\
\hline WSBC 10688 & VI & $2.53 \pm 0.08$ & $0.88 \pm 0.04$ & $1.92 \pm 0.10$ & NG & $2.09 \pm 0.10$ & $0.67 \pm 0.04$ \\
\hline WSBC 10204 & & $4.00 \pm 0.21$ & $0.94 \pm 0.19$ & $2.39 \pm 0.18$ & NG & $3.59 \pm 0.04$ & $0.54 \pm 0.07$ \\
\hline NVH883/00 & & NG & NG & NG & - & - & - \\
\hline NVH 391-98 & VII & & & NG & - & - & - \\
\hline 08CEB44 & & & & $1.45 \pm 0.26$ & - & - & - \\
\hline
\end{tabular}

a Values of optical density measured at the stationary growth phase.

b No growth. 
Version définitive du manuscrit publiée dans / Final version of the manuscript published in :

Journal of Microbiological Methods (2014), Vol. 105, p. 54-58, DOI: 10.1016/j.mimet.2014.07.006

Journal homepage: http://www.elsevier.com/locate/jmicmeth

Table 4

Capacity of B. cereus to sporulate in various media in aerobiosis and anaerobiosis.

\begin{tabular}{|c|c|c|c|c|c|c|c|}
\hline \multirow[b]{2}{*}{ Strains } & \multirow[b]{2}{*}{ Phylogenetic groups } & \multicolumn{2}{|l|}{ MOD } & \multicolumn{2}{|l|}{$\mathrm{CCY}$} & \multicolumn{2}{|l|}{ MODS } \\
\hline & & Aerobiosis & Anaerobiosis & Aerobiosis & Anaerobiosis & Aerobiosis & Anaerobiosis \\
\hline D15 & & $-{ }^{a}$ & - & $+++^{\mathrm{d}}$ & - & +++ & $+{ }^{\mathrm{b}}$ \\
\hline KBAA5 & II & - & - & +++ & - & +++ & + \\
\hline INRA 15 & & - & - & +++ & - & +++ & + \\
\hline AH187 & & - & - & +++ & - & +++ & $++^{\mathrm{c}}$ \\
\hline F837/76 & III & - & - & +++ & - & +++ & ++ \\
\hline F4433/73 & & - & - & +++ & - & +++ & + \\
\hline $\mathrm{F} 4430 / 73$ & & - & - & +++ & - & +++ & ++ \\
\hline ATCC14579 & IV & - & - & +++ & - & +++ & ++ \\
\hline NVH1230 & & - & - & +++ & - & +++ & + \\
\hline F2769/77 & & - & - & +++ & - & +++ & + \\
\hline NVH 141/1-01 & V & - & - & +++ & - & +++ & + \\
\hline UHDAM TSP9 & & - & - & +++ & - & +++ & + \\
\hline KBAB4 & & - & - & +++ & - & +++ & + \\
\hline WSBC 10688 & VI & - & - & +++ & - & +++ & + \\
\hline WSBC 10204 & & - & - & +++ & - & +++ & + \\
\hline NVH883/00 & & - & - & - & - & - & - \\
\hline NVH 391-98 & VII & - & - & - & - & - & - \\
\hline 08CEB44 & & - & - & +++ & - & - & - \\
\hline
\end{tabular}

a No growth.

b Low sporulation ( $10^{1}$ to $10^{3} \mathrm{CFU} \mathrm{ml} \mathrm{m}^{-1}$ ).

c Moderate sporulation $\left(10^{4}\right.$ to $\left.10^{6} \mathrm{CFU} \mathrm{ml}^{-1}\right)$.

d High sporulation $\left(10^{7}\right.$ to $10^{9} \mathrm{CFU} \mathrm{ml}^{-1}$ ).

2009, Zigha et al., 2006). This medium supports anaerobic growth of the $B$. cereus strains, but our results showed it to be inefficient for their sporulation (Tables 3,4). Therefore, modifications were made fortezzo and Setloto the MOD medium to improve its efficiency for the sporulation of the $B$. cereus strains. For this purpose, composition of the new medium must be as close as possible to that of the traditional sporulation media. To do this, we added minerals usually present in sporulation media and necessary for the development of spores and then bacilli (Palop et al., 1999). Based on sporulation medium CCY, $\mathrm{MgCl}_{2}, \mathrm{MnCl}_{2}$, $\mathrm{ZnCl}_{2}$ and $\mathrm{CaCl}_{2}$ were added to the MOD medium at the same concentrations. In addition, we reduced the glucose concentration present in the MOD medium because in the sporulation media, glucose is usually either at low concentration such as in FNA and $2 \times$ SG media, used for Bacillus subtilis (Nicholson and Setlow, 1990) or absent such as in CCY medium used for B. cereus (Planchon et al., 2011). It was shown that sporulation was repressed in the presence of excess glucose. In the previous work of De Vries et al. (2004), a growth and sporulation medium used for B. cereus ATCC 14579 strain contained $10 \mathrm{mM}$ glucose. In our medium, this carbon source is particularly important for the anaerobic conditions given that without glucose, no growth occurred. It was therefore important to determine the minimal concentration of glucose for good growth in order to have a reasonable spore production for characterization. Also, the MOD medium is a chemically defined medium, rich in amino acids $\left(10 \mathrm{~g} \mathrm{l}^{-1}, 15 \mathrm{AA}\right)$. It had previously been tested with its concentration of amino acids halved with no negative effect on growth (data not shown). Additionally, in the sporulation medium CCY, a mixture of amino acids and peptides was found with a low concentration $\left(2.5 \mathrm{~g} \mathrm{l}^{-1}\right)$. Finally, for uncontrolled batch cultures, $100 \mathrm{mM}$ of potassium phosphate buffer was added to limit the $\mathrm{pH}$ decrease during growth due to metabolites that acidify the medium. The MOD medium supplemented with minerals, buffer and with a final concentration of $10 \mathrm{mM}$ glucose, called MODS, was used for the production of $B$. cereus spores.

In aerobiosis, MODS and CCY media were efficient for the sporulation of all the strains belonging to phylogenic groups II, III, IV, V and VI. However, for phylogenic group VII, no growth and no spores were produced in aerobiosis or anaerobiosis in any tested medium, except for one strain that produced spores in CCY medium only in aerobiosis. This could be due to the auxotrophic character of this group.

Our results show that MODS medium provides an appropriate culture medium for both the growth and sporulation of $B$. cereus. In addition, unlike CCY medium, MODS medium was also efficient in anaerobiosis for growth and sporulation.

In anaerobiosis, sporulation capacity in MODS medium was lower than that in aerobiosis. The previous results showed that a low concentration of oxygen led to a lower spore production on several species of the genus Bacillus (Couchot and Maier, 1974). Other experiments reported a lower spore production of Bacillus thuringiensis, genetically close to Bacillus cereus, under $\mathrm{O}_{2}$ limitation compared with cultures with $\mathrm{O}_{2}$ (Avignonerossa et al., 1992; Finlay et al., 2002; Foda et al., 1985).

In conclusion, we have developed an appropriate chemically defined medium, called MODS, to study the growth and sporulation of the $B$. cereus strains in both the presence and absence of oxygen. These findings provide new knowledge on $B$. cereus behavior in an anaerobiosis environment that was hitherto lacking.

\section{Acknowledgments}

Amina Aicha Abbas received a fellowship from the Programme Intergouvernemental Franco-Algérien. This work was supported by a grant from the Agence Nationale de la Recherche under the project Food-Redox, ANR-11-ALID-001-04.

\section{References}

Avignonerossa, C., Arcas, J., Mignone, C., 1992. Bacillus-thuringiensis growth, sporulation and delta-endotoxin production in oxygen limited and nonlimited cultures. World J. Microbiol. Biotechnol. 8, 301-304.

Carlin, F., Girardin, H., Peck, M.W., Stringer, S.C., Barker, G.C., Martinez, A., Fernandez, A., Fernandez, P., Waites, W.M., Movahedi, S., van Leusden, F., Nauta, M., Moezelaar, R., Del Torre, M., Litman, S., 2000. Research on factors allowing a risk assessment of spore-forming pathogenic bacteria in cooked chilled foods containing vegetables: a FAIR collaborative project. Int. J. Food Microbiol. 60, 117-135.

Ceuppens, S., Boon, N., Uyttendaele, M., 2013. Diversity of Bacillus cereus group strains is reflected in their broad range of pathogenicity and diverse ecological lifestyles. FEMS Microbiol. Ecol. 84, 433-450.

Clavel, T., Carlin, F., Lairon, D., Nguyen-The, C., Schmitt, P., 2004. Survival of Bacillus cereus spores and vegetative cells in acid media simulating human stomach. J. Appl. Microbiol. 97, 214-219.

Couchot, K.R., Maier, S., 1974. Anaerobic sporulation in facultatively anaerobic species of the genus Bacillus. Can. J. Microbiol. 20, 1291-1296.

de Vries, Y.P., Hornstra, L.M., de Vos, W.M., Abee, T., 2004. Growth and sporulation of Bacillus cereus ATCC 14579 under defined conditions: temporal expression of genes for key sigma factors. Appl. Environ. Microbiol. 70, 2514-2519. 
Version définitive du manuscrit publiée dans / Final version of the manuscript published in :

Journal of Microbiological Methods (2014), Vol. 105, p. 54-58, DOI: 10.1016/ị.mimet.2014.07.006

Journal homepage: http://www.elsevier.com/locateijmicmeth

de Vries, Y.P., Atmadja, R.D., Hornstra, L.M., de Vos, W.M., Abee, T., 2005. Influence of glutamate on growth, sporulation, and spore properties of Bacillus cereus ATCC 14579 in defined medium. Appl. Environ. Microbiol. 71, 3248-3254.

Donnellan Jr., J.E., Nags, E.H., Levinson, H.S., 1964. Chemically defined, synthetic media for sporulation and for germination and growth of Bacillus subtilis. J. Bacteriol. 87 332-336.

Duport, C., Thomassin, S., Bourel, G., Schmitt, P., 2004. Anaerobiosis and low specific growth rates enhance hemolysin BL production by Bacillus cereus F4430/73. Arch. Microbiol. 182, 90-95.

Ehling-Schulz, M., Fricker, M., Scherer, S., 2004. Identification of emetic toxin producing Bacillus cereus strains by a novel molecular assay. FEMS Microbiol. Lett. 232, 189-195.

Ellar, D.J., Lundgren, D.G., 1966. Fine structure of sporulation in Bacillus cereus grown in a chemically defined medium. J. Bacteriol. 92, 1748-1764.

Fernandez, A., Salmeron, C., Fernandez, P.S., Martinez, A., 1999. Application of a frequency distribution model to describe the thermal inactivation of two strains of Bacillus cereus. Trends Food Sci. Technol. 10, 158-162.

Finlay, W.J.J., Logan, N.A., Sutherland, A.D., 2002. Bacillus cereus emetic toxin production in relation to dissolved oxygen tension and sporulation. Food Microbiol. 19, 423-430.

Foda, M.S., Salama, H.S., Selim, M., 1985. Factors affecting growth physiology of Bacillus thuringiensis. Appl. Microbiol. Biotechnol. 22, 50-52.

Glatz, B.A., Goepfert, J.M., 1976. Defined conditions for synthesis of Bacillus cereus enterotoxin by fermenter-grown cultures. Appl. Environ. Microbiol. 32, 400-404.

Guinebretiere, M.H., Thompson, F.L., Sorokin, A., Normand, P., Dawyndt, P., Ehling-Schulz, M., Svensson, B., Sanchis, V., Nguyen-The, C., Heyndrickx, M., De Vos, P., 2008. Ecological diversification in the Bacillus cereus group. Environ. Microbiol. 10, 851-865.

Hageman, J.H., Shankweiler, G.W., Wall, P.R., Franich, K., McCowan, G.W., Cauble, S.M. Grajeda, J., Quinones, C., 1984. Single, chemically defined sporulation medium for Bacillus-subtilis-growth, sporulation, and extracellular protease production. J. Bacteriol. 160, 438-441.

Meyer, W., Tholozan, J.L., 1999. A new growth and in vitro sporulation medium for Clostridium perfringens. Lett. Appl. Microbiol. 28, 98-102.

Moir, A., Corfe, B.M., Behravan, J., 2002. Spore germination. Cell. Mol. Life Sci. 59, 403-409. Nicholson, W.L., Setlow, P., 1990. Sporulation, germination and outgrowth. In: Harwood, C.R., Cutting, S.M. (Eds.), Molecular biological methods for Bacillus. United Kingdom, John Wiley \& Sons Ltd., Chichester, pp. 391-450.

Nguyen Thi Minh, H., Durand, A., Loison, P., Perrier-Cornet, J.-M., Gervais, P., 2011. Effect of sporulation conditions on the resistance of Bacillus subtilis spores to heat and high pressure. Appl. Microbiol. Biotechnol. 90, 1409-1417.

Ouhib, O., Clavel, T., Schmitt, P., 2006. The production of Bacillus cereus enterotoxins is influenced by carbohydrate and growth rate. Curr. Microbiol. 53, 222-226.
Ouhib-Jacobs, O., Lindley, N.D., Schmitt, P., Clavel, T., 2009. Fructose and glucose mediates enterotoxin production and anaerobic metabolism of Bacillus cereus ATCC14579T. J. Appl. Microbiol. 107, 821-829.

Palop, A., Sala, F.J., Condon, S., 1999. Heat resistance of native and demineralized spores of Bacillus subtilis sporulated at different temperatures. Appl. Environ. Microbiol. 65, 1316-1319.

Planchon, S., Dargaignaratz, C., Levy, C., Ginies, C., Broussolle, V., Carlin, F., 2011. Spores of Bacillus cereus strain KBAB4 produced at $10{ }^{\circ} \mathrm{C}$ and $30{ }^{\circ} \mathrm{C}$ display variations in their properties. Food Microbiol. 28, 291-297.

Ramaley, R.F., Burden, L., 1970. Replacement sporulation of Bacillus subtilis 168 in a chemically defined medium. J. Bacteriol. 101, 1-8.

Rosenfeld, E., Duport, C., Zigha, A., Schmitt, P., 2005. Characterization of aerobic and anaerobic vegetative growth of the food-borne pathogen Bacillus cereus F4430/73 strain. Can. J. Microbiol. 51, 149-158.

Senouci-Rezkallah, K., Schmitt, P., Jobin, M.P., 2011. Amino acids improve acid tolerance and internal pH maintenance in Bacillus cereus ATCC14579 strain. Food Microbiol $28,364-372$.

Setlow, P., 2006. Spores of Bacillus subtilis: their resistance to and killing by radiation, heat and chemicals. J. Appl. Microbiol. 101, 514-525.

Setlow, P., Johnson, E.A., 2007. Spores and their signifcance. Curr. Opin. Microbiol. 6, $550-556$.

Setlow, B., Cowan, A.E., Setlow, P., 2003. Germination of spores of Bacillus subtilis with dodecylamine. J. Appl. Microbiol. 95, 637-648.

Stewart, G., Johnstone, K., Hagelberg, E., Ellar, D.J., 1981. Commitment of bacterial-spores to germinate - a measure of the trigger reaction. Biochem. J. 198, 101-106.

Tam, N.K.M., Uyen, N.Q., Hong, H.A., Duc, L.H., Hoa, T.T., Serra, C.R., Henriques, A.O., Cutting, S.M., 2006. The intestinal life cycle of Bacillus subtilis and close relatives. J. Bacteriol. 188, 2692-2700.

Thomassin, S., Jobin, M.P., Schmitt, P., 2006. The acid tolerance response of Bacillus cereus ATCC14579 is dependent on culture $\mathrm{pH}$, growth rate and intracellular $\mathrm{pH}$. Arch. Microbiol. 186, 229-239.

Ting, M.N., Fung, D.Y., 1972. Chemically defined medium for growth and sporulation of Clostridium perfringens. Appl. Microbiol. 24, 755-759.

Zigha, A., Rosenfeld, E., Schmitt, P., Duport, C., 2006. Anaerobic cells of Bacillus cereus F4430/73 respond to low oxidoreduction potential by metabolic readjustments and activation of enterotoxin expression. Arch. Microbiol. 185, 222-233. 